Gastroia: Journal of Gastronomy and Travel Research, Vol. 5, Issue 2,277-301 , 2021

Pazarlama Karmasından Hareketle Coğrafi İşaretli Ürün Algısı: Mersin Örneği

Ozan GÜLER, Metin ÖZTÜRK

PAZARLAMA KARMASINDAN HAREKETLE COĞRAFİ ISSARETLİ ÜRÜN ALGISI: MERSIN ÖRNEĞİ ${ }^{1}$

Geographical Indicated Product Perception Based on the Marketing Mix: Case of Mersin

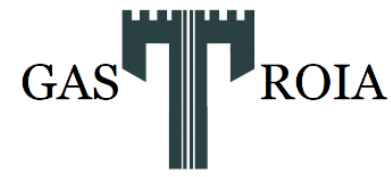

\section{Yayın Bilgileri}

Kabul tarihi:09.06.2021

Yayın tarihi: 16.08.2021

\author{
İletişim Bilgileri \\ * ozanguler17@gmail.com \\ ** ozturkmetin14@gmail.com
}

\begin{abstract}
* Ozan GÜLER
** Metin ÖZTÜRK

\section{ÖZET}

$\mathrm{Bu}$ çalışmanın amacı pazarlama karması elemanlarından hareketle tüketicilerin coğrafi işaretli ürünlere yönelik algılarını ve davranışsal tutumlarını ölçmektir. Bu amaçla, Mersin'de yaşayan tüketicilerin tantuni, cezerye ve kerebiç ürünlerinden algıladığı pazarlama karması algısı (ürün, fiyat, tutundurma) ve bu ürünlere yönelik davranışsal tüketim niyetleri araştırılmıştır. Araştırma, betimleyici amaçla nicel araştırma yöntemi ve tarama modelinde tasarlanmıştır. Veriler anketler aracılığıyla ve bırak-topla temas tekniği ile toplanmıştır. Kolayda örnekleme tekniği ile 317 anket toplanmıştır. Sapan analizi sonucunda 42 anket veri havuzundan çıkarılmış ve analizler 275 geçerli anket üzerinden gerçekleştirilmiştir. Bulgulardan hareketle, yerli halkın üç ürünü de şehrin imajı açısından önemli bulduğu anlaşılmaktadır. Tantuni ve cezerye ürünlerine yönelik hem pazarlama performansı algısının hem de davranışsal tüketim eğiliminin yüksek olduğu görülmektedir. Buna karşın kerebiç tatlısı ile ilgili algı ve tutumlar diğer iki ürüne göre istatistiksel olarak anlamlı şekilde düşüktür. Bu noktada olumsuz düşünce ve tutumların kerebiçin fiyat ve tanıtım eksikliğinden kaynaklandığı görülmektedir. Araştırma, alanyazına ve uygulayıcılara yönelik çıktılar ve öneriler ile sonlandırılmıştır.
\end{abstract}

Anahtar Kelimeler: Gastronomik Miras, Gastronomik Sürdürülebilirlik, Pazarlama Karması, Coğrafi İşaretli Ürün, Mersin

\begin{abstract}
The aim of this study is to investigate the perceptions and behavioral attitudes of consumers towards geographically indicated products based on the marketing mix elements. Thus, the marketing mix perception (product, price, promotion) perceived by the consumers living in Mersin from tantuni, cezerye and kerebiç products and behavioral consumption intentions were investigated. The research designed in quantitative research method and scanning model with the descriptive purpose. The data were collected through questionnaires and with the drop-ball contact technique. Data were collected through convenience sampling technique and totally 317 questionnaires collected. As a result of outlier analysis 42 questionnaires were removed from the data pool and analyzes were conducted over 275 valid questionnaires. Based on the findings, it was understood that the local people evaluate all three products as valuable in terms of the city image. It was seen that both the perception of marketing performance and behavioral consumption tendency towards tantuni and cezerye products were quite high. On the other hand, marketing perceptions and loyalty attitudes about the kerebiç dessert are statistically significantly lower than the other two products. At this point, it was revelaed that the negative thoughts and attitudes towards kerebiç dessert stem from its' high prices and lack of publicity. The research was concluded with discussion and recommendations for the literature and practitioners.
\end{abstract}

Keywords: Gastronomic Heritage, Gastronomic Sustainability, Marketing Mix, Geographically Indicated Product, Mersin

\footnotetext{
${ }^{1}$ Bu Çalışma İçin Mersin Üniversitesi Sosyal Bilimler Etik Kurulu'ndan 20/11/2020 tarihli ve 38 karar numaralı "Etik Kurul Onayı" alınmıştır.
} 


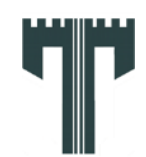

Gastroia: Journal of Gastronomy and Travel Research, Vol. 5, Issue 2,277-301 , 2021

Pazarlama Karmasından Hareketle Coğrafi İşaretli Ürün Algısı: Mersin Örneği

Ozan GÜLER, Metin ÖZTÜRK

\section{GÍRİs}

Günümüz çağı sıklıkla tüketim çağı olarak adlandırılmaktadır. Tüketim talebi birçok noktada arzın yetişemeyeceği boyutlara çıkmaktadır. Bu nedenle hem üreticiler hem de pazarlamacılar sürekli yeni mal ve hizmetlerin hayatımıza girmesi noktasında yeni arayışlara girmekteler (Gökovalı, 2007: 141). Bu durum bir yandan mal ve hizmetlerde taklit ve tağşiş sorunlarına yol açarak kalite sorununu ortaya çıkarmakta iken (Çam, Ayaydın, Pala ve Barut 2018: 71), diğer yandan bölgelerin gastronomik mirasına zarar verebilmektedir (Sünnetçioğlu, Can ve Durlu-Özkaya, 2012: 960). Somut olmayan bir kültürel miras olarak değerlendirilen gastronomik miras; bir bölge ya da coğrafyadaki kuşaktan kuşağa aktarılan yemek pişirme tarzları, saklama koşulları, geleneksel üretim ve tüketim şekilleri vb. yiyecek ve içecek faaliyetlerinin tümünü kapsayan değerler olarak tanımlanabilir. Dolayısıyla gastronomik miras bir kültürü tanıyabilmek için en önemli araçlardan birisidir (Yüncü, 2010: 27-28; Çapar ve Yenipınar, 2016: 104). Gastronomik mirasın en önemli unsurlarından birisi yöresel yiyeceklerdir. Türkiye, binlerce yıl içerisinde etkilendiği ve ilişkili olduğu farklı kültürel çeşitliliğin sayesinde eşsiz bir yöresel yemek mirasına sahiptir. 7 farklı coğrafi bölgenin de kendisine has yemek hazırlama, pişirme, sunma ve saklama teknikleri bir diğerinden farklılaşır. Öyle ki, UNESCO Somut Olmayan Kültürel Mirası listesinde, Türkiye'ye ait olan 18 miras içerisinde yöresel yiyecekleri temsil eden "Geleneksel Tören Keşkeği”, "Mesir Macunu Festivali”, "Türk Kahvesi ve Geleneği” ve "İnce Ekmek Yapma ve Paylaşma Kültürü: Lavaş, Katırma, Jupka, Yufka” dört miras bulunmaktadır (Unesco, 2019).

Gastronomik mirasın korunmasına yönelik kullanılan eski yöntemlerden birisi de "Coğrafi İşaretleme” yöntemidir (Bekar ve Karakulak, 2017: 156). Yöresel ürünlerin ayırt ediciliğini tasdikleyen bir yöntem olarak coğrafi işaretleme (Bekar ve Karakulak, 2017: 156) coğrafi kaynak gösteren ürün adlarının koruma altına alınmasını sağlayarak (Tanrıkulu, 2007: 178; Mercan ve Üzülmez, 2014: 72) gastronomik mirasın sürdürülebilirliğine destek olur (Tanrıkulu, 2007:181; Akbaba ve Kendirci, 2016: 115; Toklu, Ustaahmetoğlu ve Öztürk Küçük, 2016: 147). Bir çok ülke, coğrafi işareti yerel, tarımsal, ekolojik ve hatta kültürel özelliklerin bir yansıması olarak tanımaktadır (Giovannucci, Barham ve Pirog, 2010: 103). Coğrafi işaretli ürünler gastronomik mirasın sürdürülebilirliği, yerel kalkınma ve kaliteli ürün tüketilmesi gibi faydalar açısından önemli olduğu kadar gastronomi turizmi açısından da önemli bir konudur. Yöresel yemekler aynı zamanda gastronomi turizminin de tetikleyicisi olmuş ve ziyaretçiler için "yemek kültürü” tek başına bir ziyaret motivasyonu haline gelmiştir (Yüncü, 2010: 29; Lertputtarak, 2012: 111). Bir bölgenin sahip olduğu mutfak mirası, çok değerli bir destinasyon çekim unsuru haline gelerek turizm pazarlamasının konusu haline gelmiştir (Cömert, 2014: 65). Bu noktada yerli halkın coğrafi işaretli ürünlere bakış açısı da araştırılması önemli konulardan birisi haline gelmektedir. Yerli halkın gerek coğrafi işaretli ürün algısının ya da coğrafi işaretli ürün olarak tescillenmiş 


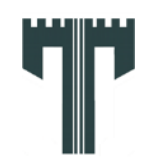

Gastroia: Journal of Gastronomy and Travel Research, Vol. 5, Issue 2,277-301 , 2021

Pazarlama Karmasından Hareketle Coğrafi İşaretli Ürün Algısı: Mersin Örneği

Ozan GÜLER, Metin ÖZTÜRK

gastronomik ürünler ile ilgili düşüncelerinin olumsuz olduğu bir noktada, coğrafi işaret tescilinin hem gastronomik mirasın sürdürülebilirliği hem de turistik çekicilik anlamında istenen sonuçlar vermesi zorlaşır. Buradan hareketle gerçekleştirilen bu araştırma, Mersin'de yaşayan yerli halkın Tantuni, Cezerye ve Kerebiç ürünlerinden hareketle coğrafi işaretli ürünlere yönelik düşüncelerini ve tutumlarını öğrenmeyi amaçlamıştır.

Coğrafi işaretli ürünler üzerine gerçekleştirilen araştırmalar incelendiğinde hem yerli hem de yabancı alanyazında en çok üzerinde durulan konunun fazladan ödeme yapma niyetine etki eden unsurların araştırılması olduğu anlaşılmaktadır. Yerli alanyazın bu konuyu coğrafi işaretlerden algılanan etkiler (ekonomik destek, kültür ve gelenek, kalite ve güvenilirlik) kapsamında araştırırken (Aytop ve Şahin, 2014; Toklu vd. 2016; Çam vd., 2018; Duman, Tanrısever ve Pamukçu, 2019; Toklu ve Pekerşen, 2019), yabancı alanyazındaki araştırmalar fazladan ödeme yapma niyetini, çoğunlukla pazarlama karması elemanlarından (4p) hareketle ölçmeye çalışmıştır (Adelaja, Brumfield ve Lininger, 1990; Patterson, 1999; Jekanowski, Williams ve Schick, 2000; McCluskey ve Loureiro, 2003; Aprile, Caputo ve Nayga, 2012; Somsong, McNally ve Hsieh, 2019). Yerel ürünler ve coğrafi işarete sahip ürünler ilgili tüketici davranışları üzerine yapılan çalışmalar (örn., Zepeda ve Leviten-Reid, 2004; Chambers ve ark., 2007; Lim ve Hu, 2012) olumlu tutumların her zaman satın alma davranışa dönüşmediğini göstermektedir. Tüketicilerin olumlu tutumları ile gerçek davranışları arasında boşluklar mevcuttur (Feldman ve Hamm, 2015: 158). Dolayısıyla coğrafi işaretli ürünlerin etkisinin fazladan ödeme yapma niyeti ile ilişkilendiren araştırmalar, farklı tüketici sınıflarının algılarını öğrenerek karşılaştırmalar yoluyla genel eğilimleri ortaya koymaktadır (Feldman ve Hamm, 2015: 158).

$\mathrm{Bu}$ çalışmada ise diğer araştırmalardan farklı olarak tıpkı Somsong, McNally ve Hsieh'in (2019) yaptığı gibi tüketicilerin coğrafi işaretli ürün algısı, pazarlama karması elemanları ve tüketici sadakati kavramsallaştırmasından hareketle araştııılmıştır. Dolayısıyla araştırmanın merkezine coğrafi işaretli ürünlerin algılanan pazarlama performansları ile tüketmeye devam etme, olumlu konuşma ve başkalarına önerme gibi davranışsal niyetler koyulmuştur. $\mathrm{Bu}$ açıdan araştırma hem alanyazına katkı sunma hem de şehrin gastronomi turizmi paydaşları için faydalı bilgiler ortaya koymaya potansiyeline sahiptir.

\section{KAVRAMSAL ÇERÇEVE}

\subsection{Coğrafi İşaret Kavramı}

Dünya'da Paris Sözleşmesi ile 1883 yılında uygulamaya koyulan coğrafi işaretleme, ülkemizde 1995 y1lında uygulamaya konulmuştur (Üzümcü, Alyakut ve Akpulat, 2017: 133). Coğrafi işaret, tüketiciler için ürünün kaynağını, karakteristik özelliklerini ve ürünün söz konusu karakteristik özellikleri ile coğrafi alan arasındaki bağlantıyı gösteren ve garanti eden kalite işaretidir (Giovannucci vd., 2010: 102). Türkiye Cumhuriyeti 6769 sayılı Sınai 


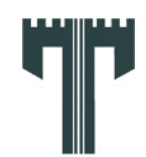

Gastroia: Journal of Gastronomy and Travel Research, Vol. 5, Issue 2,277-301 , 2021

Pazarlama Karmasından Hareketle Coğrafi İşaretli Ürün Algısı: Mersin Örneği

Ozan GÜLER, Metin ÖZTÜRK

Mülkiyet Kanunu'nun 34 üncü maddesine göre; Coğrafi işaret “Belirgin bir niteliği, ünü veya diğer özellikleri bakımından kökenin bulunduğu yöre, alan, bölge veya ülke ile özdeşleşmiş ürünü gösteren işarettir” (Türk Patent ve Marka Kurumu, 2021a) şeklinde tanımlanır. Coğrafi işaret süreci iyi yapılandırıldığında ve yönetildiğinde bölgesel düzeyde geniş ve adil kırsal kalkınma için mükemmel bir aracı rolü üstlenebilir (Giovannucci vd. 2010: 103). Bu işaret sayesinde ürünler tescillenerek kalitesi, gelenekselliği, yöreden elde edilen hammaddesi ile yerel niteliklere bağlı olarak belli bir üne kavuşmuş ürünlerin korunması sağlanır (Duman vd., 2019: 821; Çalışkan ve Koç, 2012: 197; Doğan, 2015: 60). Yasalarla korunan bir marka, ürünün güvenirliliğini arttırarak pazarda itibar sahibi olmasını destekleyebilir (Giovannucci vd. 2010: 103).

Ticari markalar ve coğrafi işaretler birbirini tamamlayan ancak farklı kavramlardır. Ticari markalar, üreticinin bireysel ürünüdür ve hakları sahibine aittir. Benzer ürünler birden fazla kişi veya kişiler tarafından üretilebilir. Birinin ürünlerini diğerinin ürünlerinden ayırt etmek için marka kullanılır. Buna karşılık coğrafi işaretler bir bölgenin ortak hakkıdır ve kökenleriyle ilişkili belirli bir kalite ve güvene sahip özellikleri tanımlar (Giovannucci vd. 2010: 104). Coğrafi işaretler, menşe adı ya da mahreç işareti olarak tescil edilir ve gıdadan, madene, el sanatlarından, sanayi ürünlerine kadar geniş bir kullanım alanı vardır. Menşe adı; temel özelliklerini sınırları belirlenmiş bir alandan alan, üretim aşamalarının tamamı bu alan dâhilinde gerçekleştirilen ve niteliklerini sadece ait oldukları yerden tamamlayabilen Antep fistığı, Erzincan tulum peyniri ve Isparta gülü gibi örneklendirilebilen ürünlerdir (Oraman, 2015: 77). Mahreç işareti ise; "Belirli bir niteliği, ünü gibi belirli bir coğrafi alan ile özdeşleşmiş olan; üretim, işleme ya da diğer işlemlerinden en az birinin belirlenmiş coğrafi alan içinde gerçekleşmesi gereken, Antep baklavası, Hatay künefesi, Mersin tantunisi gibi örneklendirilebilecek ürünlerin konu olduğu coğrafi işaretlerdir” (Oraman, 2015: 77). Geleneksel ürün ise; "Menşe adı veya mahreç işareti kapsamına girmeyen ilgili piyasada bir ürünü tarif etmek için geleneksel olarak en az otuz yıl süreyle kullanıldiğı kanıtlanan adlardır" (Türk Patent ve Marka Kurumu, 2021a).

Coğrafi işaretleme bir yandan yöresel ürünleri tescilleyip, onları koruma altına alırken diğer yandan da yerel ve bölgesel olarak markalaşma, imaj, tanınma ve ekonomik anlamda olumlu katk1lar sunmayı amaçlar. (Orhan, 2010: 244; Mercan ve Üzülmez, 2014: 72; Toklu vd., 2016: 147; Bucak, 2018: 378; Doğan, 2015: 59). Coğrafi İşaretli ürünler aynı zamanda tüketicilerde pozitif kalite algısı oluşturan ürünlerdir (Gökovalı, 2007: 144; Durlu, Sünnetçioğlu ve Can, 2013: 16; Mercan ve Üzülmez, 2014: 72; Çalışkan ve Koç, 2012: 197; Doğan, 2015: 60) ve sağliklı ürün algısını tetikleyerek tüketicilerin tercihlerini etkileyen en önemli unsur olan güvenirliliği olumlu yönde etkiler (Lee, Niode, Simone ve Bruhn, 2012: 531-532; Oraman, 2015: 78-79; Somsong, McNally ve Hsieh, 2019: 152-153; Doğan, 2015: 60). Özetle bir ürünün coğrafi işaretle etiketlenmesi i) ürünün korunması, ii) üreticinin 


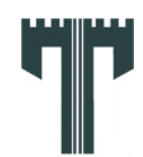

Gastroia: Journal of Gastronomy and Travel Research, Vol. 5, Issue 2,277-301 , 2021

Pazarlama Karmasından Hareketle Coğrafi İşaretli Ürün Algısı: Mersin Örneği

Ozan GÜLER, Metin ÖZTÜRK

korunması, iii) tüketiciyi koruması açısından ve iv) milli ve kültürel değerlerinin korunması açısından belirgin faydalar sağlar (Tanrıkulu, 2007:178).

Türk Patent ve Marka Kurumu'nun ci.turkpatent.gov.tr isimli internet adresinden alınan verilere göre (09.06.2021) genel olarak tescillenen toplam 770 ürün bulunmaktadır ve 707 adet ürünün tescil işlemleri devam etmektedir (Türk Patent ve Marka Kurumu, 2021b). Coğrafi işaret alarak tescillenen ürünlerin \% 64'ü Mahreç İşareti alırken; \%35,6'sı Menşe Adı alarak tescillenmiştir. Geleneksel Ürün Adı ile tescil alan ürünlerin oranı ise \%0,4'tür (Türk Patent ve Marka Kurumu, 2021c). 2021 yılı Haziran ayı itibariyle Türkiye'de gastronomi bağlamında 621 adet ürün bulunmaktadır. Bu ürünler içerisinde en yüksek orana sahip ürün sınıfları \%25,9 (199 adet) ile işlenmiş ve işlenmemiş meyve ve sebzeler ile mantarlar ve \%20,9 (160 adet) ile yemekler ve çorbalar ve \%15,9 (122 adet) ile firıncılık ve pastacılık mamulleridir (Türk Patent ve Marka Kurumu, 2021d).

\subsection{Mersin'in Coğrafi İşaretli Ürünleri}

2021 yılı Haziran ayı itibariyle Mersin'de tescillenmiş 18 adet coğrafi işaretli gastronomik ürün bulunmaktadır. Bunların içinde Anamur Muzu (2003), Erdemli Lamas Limonu (2019), Erdemli Muzu (2019), Mut Kayısısı (2007), Mut Zeytinyağı (2018), Silifke Çileği (2019), Tarsus Beyazı Üzümü (2005), Tarsus Sarıulak Zeytini (2018), Tarsus Sarıulak Zeytinyağı (2021), Tarsus Yayla Bandırması (2008) olmak üzere 10 ürün Menşe adı olarak tescillenmiştir. Ek olarak, Mersin Cezeryesi (2003), Tarsus Şalgamı (2007), Mersin Tantunisi (2017), Tarsus Humusu (2017) ve Mersin Kerebici (2019), Tarsus Kebab1 (2020), Tarsus Fındık Lahmacunu (2020), Bozyazı Kavutu (2020) olmak üzere 8 ürün de Mahreç İşareti almıştır (Türk Patent ve Marka Kurumu, 2021e).

\subsection{Coğrafi İşaretli Ürün Algısı Üzerine Alanyazın Taraması}

Coğrafi işaretli ürün algısı kimi çalışmalarda herhangi bir üründen bağımsız olarak, tüketicilerin genel algıları bağlamında araştırılmış iken (örn., Feldmann ve Hamm, 2014; Toklu vd. 2016; Çam vd., 2018; Duman vd. 2019), bazı çalışmalar ise bir şehre ya da bölgeye ait bir ya da birden fazla ürün üzerinden katılımcıların coğrafi işaretli ürün algılarını araştırmıştır (örn., Adelaja, Brumfield ve Lininger, 1990; Patterson, 1999; McCluskey ve Loureiro, 2003; Aprile, Caputo ve Nayga, 2012; Aytop ve Şahin, 2014; Toklu vd. 2016; Toklu ve Pekerşen, 2019; Somsong, McNally ve Hsieh, 2019).

Feldmann ve Hamm (2014), derleme türündeki araştırmalarında 2010-2014 yılları arasında gerçekleştirilen araştırmaları incelemiş ve tüketiciler için organik ürün ve coğrafi işaretli ürün kavramlarının ayrıştığı ancak fiyat algısı açısından belirgin bir farklılık algısının olmadığını ifade etmişlerdir. Bununla beraber coğrafi işaretli ürünlere ilişkin tüketici özellikleri, algıları ve satın alma davranışlarının farklılıklarını belirlemişlerdir. Toklu vd. (2016), tüketicilerin coğrafi işaretli ürünlere olan algılarını ve bu ürünlere daha fazla ödeme 
eğilimlerini araştırdıkları çalışmalarında kültür ve gelenek, kalite ve güvenilirlik boyutlarının tüketicilerin coğrafi işaretli ürün algısını anlamlı ve olumlu olarak etkilediğini ancak ekonomik destek boyutunun anlamlı bir etkisinin bulunamadığını ortaya koymuşlardır. Ek olarak olumlu coğrafi işaret algısının tüketicilerde fazla fiyat ödeme eğilimi oluşturabileceği de bulgulanmıştır. Benzer bir araştırmayı Gümüşhane iline gelen yerli turistler örnekleminde yapan Çam vd. (2018), coğrafi işaretli ürünlerden algılan sadece ekonomik destek boyutunun tüketicilerin coğrafi işaretli ürün algılarını olumlu yönde etkilediği kültürel ve geleneksel destek ile kalite ve güvenilirlik algılarının anlamlı bir etkisinin olmadığını bulgulamışlardır.

Alanyazında coğrafi işaretli ürün algısını coğrafi işaret almış ürünler üzerinden araştıran bir dizi çalışma da mevcuttur. Adelaja, Brumfield ve Lininger (1990), New Jersey eyaletinin "Jersey Fresh" etiketli domatesi özelinde yaptıkları araştırmalarında, bu ürünün yerli halk tarafından pahalı ancak kaliteli bir ürün olarak algılandığını ve coğrafi kökeninin satın almayı teşvik eden ekstra bir özellik olarak görüldüğünü ortaya koymuşlardır. McCluskey ve Loureiro (2003) benzer bir sonuca "Washington Apple" coğrafi işaretine sahip elmalar örnekleminde ulaşarak, yüksek fiyatlı olsalar bile tercih edildiklerini bulgulamışlardır. Patterson (1999) “Arizona Grown” coğrafi işaret etiketini taşıyan gıda ürünlerinin durumunu araştırdıkları çalışmalarında, tüketicilerin Arizona'nın coğrafi işaretli ürünleri hakkında büyük ölçüde habersiz olduğunu ve bu sertifikasyon sisteminin ürün satışları üzerinde çok az veya hiç etkisi olmadığını tespit etmişlerdir. Aprile, Caputo ve Nayga, (2012) zeytinyağı örnekleminde yapmış olduğu araştırmalarında hangi coğrafi işaret etiketinin tüketicilerin fazladan ödeme yapma tercihinde daha etkili olduğunu araştırmışlardır. Elde edilen bulgular en yüksek fiyatı ödeme niyetinde ilk sırada ürünün menşei etiketinin, ikinci sırada organiklik etiketinin, üçüncü sırada natürellik (saflık) etiketinin ve son sırada ise coğrafi işaret etiketinin geldiğini göstermektedir.

Mercan ve Üzülmez (2014), nitel araştırma yöntemiyle gerçekleştirdikleri araştırmalarında Çanakkale ilinde coğrafi işaret tescili almış olan (Ezine peyniri, Bayramiç beyazı ve Çanakkale el halısı) ürünlere yönelik yerli halk algısının çoğunlukla ekonomik katkılar bağlamında oluştuğunu ortaya koymuştur. Aytop ve Şahin (2014), Kahramanmaraş’ta Gemlik Zeytini özelinde yaptıkları araştırmalarında, yerli halkın büyük oranda Gemlik zeytini hakkında bilgi sahibi olup, bu zeytini tükettiklerini ve katılımcıların \%29,8'nin Gemlik zeytini için \%25.70 daha fazla ödeme yapma eğiliminde oldukları belirtilmiştir. Toklu vd. (2016) Artvin'li tüketicilerin Artvin balına yönelik algılarını ve daha fazla ödeme eğilimine etkisini araştırmıştır. Araştırma bulgularına göre 'kalite ve güvenilirlik' algısı tüketicilerdeki Artvin balı algısını olumlu etkilerken, 'kültür ve gelenek' ile 'ekonomik destek' algıları tüketicilerdeki olumlu Artvin balı algısını etkilememektedir. Ek olarak coğrafi işaretli Artvin balı için tüketicilerin daha fazla ödeme yapma eğiliminde oldukları görülmektedir. 
Çakaloğlu ve Çağatay (2017), Finike portakalı ve Antalya Tavşan Yüreği zeytininin bir marka değeri taşıyıp taşımadığı sorusuna yanıt aramak amacıyla yaptıkları araştırmalarında coğrafi işaretli ürünlerin tüketicilerdeki fiyat yansımalarını araştırmıştır. Toplanan verilerin analizi sonucunda tüketicilerin coğrafi işaret tescilli Finike portakalına fazla fiyat ödeme olasılığının yüksek olduğu buna karşın Antalya Tavşan Yüreği zeytininin ise katılımcılarda henüz bir marka değerine ulaşmadığı için fazladan fiyat ödeme olasılığının çok düşük olduğunu belirlemişlerdir. Toklu ve Pekerşen (2019), Karaman'da yaşayan yerli halkın Divle Obruğu tulum peyniri hakkındaki bilgi ve coğrafi işaret algısının ölçülmesi amacıyla yaptıkları çalışmalarında yerli halkın peyniri duyduklarını ancak özellikleri hakkında yeterli bilgi düzeyine sahip olmadıkları belirlenmiştir. Ayrıca peynirin pazarlama faaliyetlerinin yeterli düzeyde yapılamadığı için coğrafi işaret almış bu ürünün üretiminin ve pazarlamasını teşvik edilmesi gerekliliği üzerinde durulmuştur.

Somsong, McNally ve Hsieh (2019), tüketicilerin pirinç ürünlerine yönelik algılarını pazarlama karması elemanlarından hareketle araştırmış ve geleneksel Tayland pirinci ile yenilikçi Tayland pirincine yönelik bir karşılaştırma yapmıştır. Buna göre doğu ve batılı müşterilerin pazarlama karması değişkenlerine ilişkin algıların, değer algılarını ve sadakat eğilimlerini olumlu yönde etkilediği belirlenmiştir. Duman vd. (2019), Kastamonu Ilgaz Dağı Milli Parkı'nı ziyaret eden yerli turistler örnekleminde yaptığı araştırmasında hem katılımcılar hem de paydaşlardan veri toplamıştır. Buna göre katılımcıların en olumlu algıladığı boyutlar coğrafi işarete olan hassasiyet ve coğrafi işaretli ürünleri tavsiye etme eğilimidir. Yerel paydaşların görüşleri ise coğrafi işaretlerin bölge ekonomisine katkı sağladığı, bölgenin turizm potansiyelini ve tanıtımını artırmada bir araç olabileceği yönündedir.

\section{YÖNTEM}

\subsection{Araştırmanın Amacı, Modeli ve Soruları}

Bu çalışmanın ana amacı; Mersin'de yaşayan yerli halkın Tantuni, Cezerye ve Kerebiç ürünlerinden hareketle coğrafi işaretli ürünlere yönelik düşüncelerini ve tutumlarını araştırmaktadır. Bu ana amaca ulaşabilmek için tüketicilerin öncelikle (i) coğrafi işaretli ürünlere yönelik genel algıları (ii) pazarlama karması elemanlarından ürün, fiyat ve tanıtım (tutundurma) değişkenleri aracılığıyla tantuni, cezerye ve kerebiç ürünlerine yönelik algıları ve (iii) bu ürünlere yönelik davranışsal eğilimleri ölçülmüştür. Buradan hareketle bu araştırma, yöntem olarak nicel araştırma (Büyüköztürk, vd., 2012: 12), tür olarak ise betimleyici araştırma sınıfına girmektedir (Sekeran, 1992: 96).

Araştırmanın amacına tarama modeli ile ulaşılması planlanmıştır. Tarama modelleri halen veya geçmişte var olanı olduğu gibi saptamaya/tanımlamaya çalışan, araştırmaya konu olan olay, birey veya nesneyi kendi koşulları içinde olduğu gibi tanımlamaya çalışan araştırma 


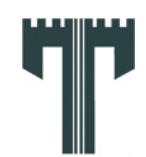

Gastroia: Journal of Gastronomy and Travel Research, Vol. 5, Issue 2,277-301 , 2021

Pazarlama Karmasından Hareketle Coğrafi İşaretli Ürün Algısı: Mersin Örneği

Ozan GÜLER, Metin ÖZTÜRK

modelidir (Karasar, 2014: 77). Yukarıda tanımlanan üç alt amaca ulaşabilmek için hem tekil hem de ilişkisel tarama modelleri bir arada kullanılmıştır. Araştırmada yerli halkın coğrafi işaret algısı ve belirli ürünlere yönelik düşüncelerini betimlendiği gibi, ürünler bağlamında istatistiksel farklılıklar olup olmadığı da araştırılmıştır. Bu açıdan tekil tarama hem ilişkisel tarama modelleri bir arada kullanılmıştır (Karasar, 2014: 79-81). Araştırmanın amacına ulaşması için cevap aranan araştırma soruları şu şekildedir;

1. Katılımcıların tantuni, cezerye ve kerebiç ürünlerini tüketme sıklıkları ve lezzet algıları nasıldir?

2. Katılımcıların coğrafi işaretli ürünlere yönelik genel algısı nasıldır?

3. Katılımcıların tantuni, cezerye ve kerebiç ürünlerinin pazarlama performansları hakkındaki algıları nasıldır?

4. Katılımcıların tantuni, cezerye ve kerebiç ürünlerine yönelik davranışsal tüketim niyetleri nasildir?

5. Katılımcıların algıladıkları pazarlama performansları coğrafi işaretli ürünün türüne göre anlamlı şekilde farklılaşır mı?

6. Katılımcıların algıladıkları davranışsal tüketim niyetleri coğrafi işaretli ürünün türüne göre anlamlı şekilde farklılaşır mı?

\subsection{Evren ve Örneklem}

Araştırmanın genel evreni Mersin ili sınırları içerisinde yaşayan tüketicilerdir. Mersin'in 2020 yılı tahmini verilere göre nüfusu 1.855 .762 'dir. Bu genel evrene ulaşmak imkânsız olduğu için örneklem üzerinde çalışılmıştır (Sekeran, 1992: 226-227). Örnekleme tekniği olarak olasılıklı olmayan örnekleme yöntemlerinden kolayda örnekleme ve amaçlı örnekleme tekniklerinden faydalanılmıştır. Amaçlı örnekleme tekniğiyle örnekleme sadece Mersin'in coğrafi işarete sahip Tantuni, Cezerye ve Kerebiç ürünlerinden herhangi birinin tadını deneyimlemiş olan kişiler dâhil edilmiştir. Kolayda örnekleme tekniğiyle ise önkoşulları karşılayan ve Mersin'in Yenişehir ilçesinde karşılaşılan tüketicilere ulaşılması hedeflenmiştir. Yenişehir'in örneklem olarak belirlenmesinin temel sebebi sahil şeridinin bulunduğu G.M.K bulvarının bu ilçede bulunmasıdır. COVID-19 pandemisinden kaynaklı uygulanan sosyal mesafe ve katı hijyen uygulamaları nedeniyle kapalı alanlardan uzak duran ve Mersin'in farklı ilçelerinde yaşayan yerli halk, akşam saatlerinde kendi sandalye ve masalarını alarak sahil kenarında vakit geçirmiştir. Pandemi koşullarından dolayı örneklem hacmi olarak alışılagelen sayılara ulaşabilmenin zorluğu göz önüne alınarak, ölçekte yer alan madde başına en az 12 kişiye ulaşabilme hedefinden hareketle $252(21 * 12)$ ve üzerinde bir örneklem hacmine ulaşılması hedeflenmiştir. 


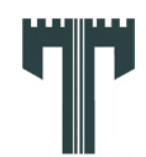

Gastroia: Journal of Gastronomy and Travel Research, Vol. 5, Issue 2,277-301 , 2021

Pazarlama Karmasından Hareketle Coğrafi İşaretli Ürün Algısı: Mersin Örneği

Ozan GÜLER, Metin ÖZTÜRK

\subsection{Veri Toplama Aracı ve Süreci}

Veri toplama aracı olarak anket tekniğine başvurulmuştur. Hazırlanan anket formlarının, 20.11.2020 tarihinde Mersin Üniversitesi Etik Kurul'u tarafından onay almasının ardından 23 Kasım 2020 - 01 Mart 2021 tarihleri arasında veri toplama süreci başlamıştır. Temas tekniği olarak Koronavirüs (Covid-19) pandemisi nedeniyle bırak ve topla tekniği uygulanmıştır. Sahil şeridinde kendi sandalye ve masalarında sohbet eden kişilere Tantuni, Cezerye ve Kerebiç ürünlerinden herhangi birinin tadına bakıp bakmadıkları sorulmuş ve evet cevabı verenlere anketler daha sonra toplanmak üzere bırakılmıştır. Anket üç bölümden oluşmaktadır. Anketin ilk bölümünde katılımcıların demografik özelliklerini ölçmeye yönelik 9 kategorik soru yer almaktadır. İkinci bölümde tüketicilerin coğrafi işaretli ürünlere yönelik genel algısını ölçmeye yönelik 6 soru yer almaktadır (Duman vd., 2019; Durusoy, 2017). Anketin üçüncü bölümünde ise Tantuni, Cezerye ve Kerebiç ürünlerinden algılanan ürün kalitesi, fiyat uygunluğu, tanıtım yeterliliği (tutundurma) ve davranışsal niyet değişkenlerini ölçmeye yönelik yönelik 15 soru yer almaktadır. Bu ifadeler Toklu vd. (2016), Durusoy (2017), Duman vd. (2019) ve Somsong, McNally ve Hsieh'in (2019) araştırmalarındaki ölçek maddelerinden derlenmiştir. Katılımcıların yanıtlara verdikleri tepki kategorileri 1= Kesinlikle Katılmıyorum, 5= Kesinlikle Katılıyorum olacak şekilde 5'li Likert tipi dereceleme ölçeği ile hazırlanmıştır. Uygulanan veri toplama süreci sonucunda 317 anket toplanmıştır. Elde edilen verilere gerçekleştirilen çoklu sapan analizi sonucunda (her bir ürün için verilen yanıtlara göre ayrı ayrı) 42 anketin normal dağılımı bozduğu anlaşılmıştır. Bunun üzerine veri setinden çıkartılan anketlerden sonra toplam 275 anket ile analiz sürecine geçilmiştir.

\subsection{Kapsam ve Veri Analiz Teknikleri}

Araştırmanın amacı bağlamında katılımcıların coğrafi işaretlere yönelik algıları, pazarlama karması elemanlarından ürün, fiyat ve tanıtım (tutundurma) değişkenlerinden hareketle ölçülmüş iken dağıtım değişkeni kapsam dışında bırakılmıştır. Mersin'in yukarıda bahsedildiği üzere coğrafi işaret almış gastronomi ürünü sayısı 16'dır. Araştırma kapsamı ise sadece Tantuni, Cezerye ve Kerebiç ile sınırlı tutulmuştur. Elde edilen verilerin analizinde istatistik paket programlarından faydalanılmıştır. Veri setindeki değişkenlere öncelikle güvenilirlik analiz uygulanmıştır. Buna göre Cronbach's Alpha istatistiğinden hareketle, katılımcıların coğrafi işaretli ürünlere yönelik genel algısını ölçen 6 maddeli ölçeğin güvenilirlik puanı 0,758, üç farklı coğrafi işaretli ürüne yönelik algısını 12 maddeli ölçeğin güvenilirlik puanı 0,961 ve davranışsal niyeti ölçen 3 maddeli ölçeğin güvenilirlik skoru 0,944 olarak bulunmuştur. Güvenilirlik analizi bulguları daha detaylı incelendiğinde, ölçeklerin güvenilirliğini bozan ve bu yüzden de çıkarılması gereken herhangi bir madde olmadığı görülmüştür. Buradan hareketle üç farklı ürüne yönelik tüketici algılarını anlamak 
Gastroia: Journal of Gastronomy and Travel Research, Vol. 5, Issue 2,277-301 , 2021

Pazarlama Karmasından Hareketle Coğrafi İşaretli Ürün Algısı: Mersin Örneği

Ozan GÜLER, Metin ÖZTÜRK

ve karşılaştırmalı veriler sunmak üzere betimleyici analizler ve fark testi analizleri gerçekleştirilmiştir.

\section{BULGULAR}

\section{1. Örnekleme Yönelik Tanımlayıcı Bulgular}

Araştırmaya katılan bireylerin demografik özelliklerine ait bilgiler Tablo 1.'de yer almaktadır. Buna göre araştırmaya 103 kadın $(\% 37,5)$ ve 172 erkek $(\% 62,5)$ katılmıştır. Katılımcıların büyük kısmı evli $(\% 62,5)$ olup, yaş aralığı olarak 18-45 yaş arasında (\%62), kişilerdir (\%37,5). Diğer örneklemi tanıtıcı bilgiler Tablo 1.'de paylaşılmıştır.

Tablo 1. Kat1lımc1ların Demografik Bulguları $(n=275)$

\begin{tabular}{|c|c|c|c|c|c|}
\hline Cinsiyet & Frekans & Yüzde \% & Meslek & Frekans & Yüzde \% \\
\hline Erkek & 172 & 62,5 & Ev hanımı & 44 & 16,0 \\
\hline Kadın & 103 & 37,5 & İşçi & 61 & 22,2 \\
\hline Toplam & 275 & 100,0 & Memur & 51 & 18,5 \\
\hline Yaş & Frekans & Yüzde \% & Esnaf & 46 & 16,7 \\
\hline $18-25$ & 67 & 24,4 & Emekli & 9 & 3,3 \\
\hline $26-35$ & 91 & 33,1 & Öğrenci & 35 & 12,7 \\
\hline $36-45$ & 73 & 26,5 & Çalışmıyor & 29 & 10,5 \\
\hline $46-55$ & 31 & 11,3 & Toplam & 275 & 100,0 \\
\hline 56 ve üzeri & 13 & 4,8 & Ĕ̆itim seviyesi & Frekans & Yüzde \% \\
\hline Toplam & 275 & 100,0 & İlköğretim & 49 & 17,8 \\
\hline $\begin{array}{l}\text { Medeni } \\
\text { durum }\end{array}$ & Frekans & Yüzde \% & Lise & 103 & 37,5 \\
\hline Bekâr & 103 & 37,5 & Ön lisans & 39 & 14,2 \\
\hline Evli & 172 & 62,5 & Lisans & 65 & 23,6 \\
\hline \multirow[t]{2}{*}{ Toplam } & 275 & 100,0 & Lisansüstü & 19 & 6,9 \\
\hline & & & Toplam & 275 & 100,0 \\
\hline
\end{tabular}


Katılımcılara araştırmanın kapsamı bağlamında ele alınan Mersin'in coğrafi işaretli ürünleri ile ilgili tüketim sıklıkları da sorulmuştur. Tablo 2.'deki bulgularda görüleceği üzere en sık tüketilen ürün Tantuni $(\%$ 61,9) olurken, ikinci sirada Cezerye $(\% 42,5)$ ve son sirada Kerebiç'e $(\% 11,4)$ gelmektedir. Katılımcıların en fazla tatmadığı ürün benzer şekilde $\% 28,7$ ile yine Kerebiç tatlısıdır. Katılımcılardan ilgili üç ürünün lezzetine yönelik düşünceleri sorulmuştur. 10 puan üzerinden bir değerlendirme yapmaları istenen katılımcıların yanıtlarından hareketle en beğenilen ürünün Tantuni olduğu, en düşük lezzetli bulunan ürünün ise Kerebiç tatlısı olduğu görülmüştür.

Tablo 2. Tüketim Sıklığı ve Lezzet Ortalamalarına Yönelik Betimleyici Bulgular (n=275)

\begin{tabular}{|c|c|c|c|c|c|c|c|c|}
\hline \multicolumn{3}{|c|}{ Tantuni } & \multicolumn{3}{|c|}{ Cezerye } & \multicolumn{3}{|c|}{ Kerebiç } \\
\hline $\begin{array}{l}\text { Siklık } \\
\text { Derecesi }\end{array}$ & Frekans & $\begin{array}{l}\text { Yüzde } \\
(\%)\end{array}$ & \begin{tabular}{|l|} 
Sıklık \\
Derecesi
\end{tabular} & Frekans & $\begin{array}{l}\text { Yüzde } \\
(\%)\end{array}$ & \begin{tabular}{|l|} 
Siklık \\
Derecesi
\end{tabular} & Frekans & $\begin{array}{l}\text { Yüzde } \\
(\%)\end{array}$ \\
\hline Hiç & 3 & 1,1 & Hiç & 18 & 6,5 & Hiç & 79 & 28,7 \\
\hline Nadiren & 41 & 14,9 & Nadiren & 73 & 26,5 & Nadiren & 100 & 36,4 \\
\hline Ara sira & 61 & 22,2 & Ara sira & 67 & 24,4 & Ara sira & 65 & 23,6 \\
\hline Sik Sik & 78 & 28,4 & Sik S1k & 63 & 22,9 & Sik Sik & 20 & 7,3 \\
\hline Çok S1k & 92 & 33,5 & Çok S1k & 54 & 19,6 & Çok Sik & 11 & 4,0 \\
\hline Toplam & 275 & 100,0 & Toplam & 275 & 100,0 & Toplam & 275 & 100,0 \\
\hline $\begin{array}{l}\text { Lezzet } \\
\text { Ort. }\end{array}$ & & & Lezzet Ort. & & & $\begin{array}{l}\text { Lezzet } \\
\text { Ort. }\end{array}$ & 5,0 & \\
\hline
\end{tabular}

\subsection{Genel ve Ürün Bazlı Coğrafi İşaret Algısına Yönelik Bulgular}

Araştırmaya katılanların coğrafi işaretli ürünlere yönelik algıları üç aşamada araştırılmıştır. İlk olarak katılımcıların herhangi bir üründen bağımsız olarak genel coğrafi işaretli ürün algıları ölçülmüştür. İkinci aşamada katılımcıların üç coğrafi işaretli ürüne yönelik algıları pazarlama karması elemanlarının etkinliği kapsamında ölçülmüştür. Üçüncü aşamada ise katılımcıların üç coğrafi işaretli ürüne yönelik davranışsal tüketim niyetleri ölçülmüştür. İlk aşama olan genel coğrafi işaretli ürün algısına yönelik 5'li Likert tipi derecelemeden hareketle elde edilen ortalama puan 3,85'tir. Dolayısıyla katımcıların coğrafi işaretli ürünlere yönelik olumluya yakın bir algıya sahip oldukları söylenebilir. Tablo 3.'te yer alan istatistiklerde görülebileceği üzere katılımcıların en olumlu algıları "geleneksel metotlarla, 
Gastroia: Journal of Gastronomy and Travel Research, Vol. 5, Issue 2,277-301 , 2021

Pazarlama Karmasından Hareketle Coğrafi İşaretli Ürün Algısı: Mersin Örneği

Ozan GÜLER, Metin ÖZTÜRK

orijinal bölgesinde üretildiğine inanıyorum" ifadesinde $(\bar{x}=4.28)$ en düşük algıları ise "gereğinden fazla pahalı olduğunu düşünmüyorum" ( $\bar{x}=3.28)$ ifadesinde ortaya çıkmıştır.

Tablo 3. Genel Coğrafi İşaretli Ürün Algısına Yönelik Betimleyici İstatistikler (n=275)

\begin{tabular}{|l|c|c|}
\hline Iffadeler & Ortalama & Standart Sapma \\
\hline $\begin{array}{l}\text { Coğrafi işaretli ürünlerin diğer ürünlerden farklı olduğunu } \\
\text { düşünüyorum.* }\end{array}$ & 3,5964 & 1,31276 \\
\hline $\begin{array}{l}\text { Coğrafi işaretli ürünlerin gereğinden fazla pahalı olduğunu } \\
\text { düşünmüyorum.* }\end{array}$ & 3,2836 & 1,19286 \\
\hline $\begin{array}{l}\text { Coğrafi işaretli ürünlerin daha lezzetli olduğunu } \\
\text { düşünüyorum. }\end{array}$ & 3,8691 &, 91478 \\
\hline $\begin{array}{l}\text { Coğrafi işaretli ürünlerin daha sağlıklı ve güvenilir olduğunu } \\
\text { düşünüyorum. }\end{array}$ & 3,9709 &, 80093 \\
\hline $\begin{array}{l}\text { Coğrafi işaretli ürünlerin daha kaliteli olduğunu } \\
\text { düşünüyorum. }\end{array}$ & 4,1200 &, 73752 \\
\hline $\begin{array}{l}\text { Coğrafi işaretli ürünlerin geleneksel metotlarla, ilgili bölgede } \\
\text { üretildiğine inanıorum. }\end{array}$ & 4,2800 &, 70824 \\
\hline \multicolumn{1}{|c|}{ Genel Ort. } & 3,8533 & 0,9445 \\
\hline
\end{tabular}

Not: İlgili ifadelerin ortalama puanları ters kodlama işleminden sonra tekrar hesaplanmıştır.

Katılımcıların coğrafi işaretli ürünlere yönelik genel algılarının ardından ikinci aşamada Mersin'in coğrafi işaretli ürünleri olan tantuni, cezerye ve kerebiçe yönelik alg1 ve düşünceleri araştırılmıştır. Pazarlama karması elemanlarından ürün kalitesi, fiyat uygunluğu ve tutundurma (tanıtım) değişkenlerine yönelik 12 ifade ile katılımcıların düşünceleri öğrenilmiştir. Tablo 4.'te paylaşılan bulgularda görüleceği üzere ortalama puanlardan hareketle en olumlu alg1 "Ürün, Mersin'in imaj1 için önemli bir üründür." ( $\bar{x}=4.48)$ ifadesinde ortaya çıkmıştır. Bu ifadenin ardından ortalama puan olarak 4 ve üzerinde puana sahip olan diğer ifadeler "Ürün hakkında olumlu yorumlar mevcuttur $(\bar{x}=4.10)$, "Ürünün herhangi bir markasını hatırlıyorum" ( $\bar{x}=4.01)$ ve "Tadı güzeldir" $(\bar{x}=4.01)$ olarak ortaya çıkmıştır. $\mathrm{Bu}$ bulgular pazarlama karması elemanları açısından incelendiğinde ürün ve tutundurma boyutlarına yönelik algıların daha yüksek olduğu, fiyat açısından ise nispeten daha olumsuz bir algı olduğu söylenebilir. Bulgular pazarlama karması elemanlarının üç boyutunu temsil eden fiyat, ürün ve tutundurmaya yönelik ifadeler açısından incelendiğinde, tantuniye yönelik tutum ve düşüncelerin diğer iki ürüne kıyasla belirgin bir şekilde çok daha olumlu olduğu görülmektedir. Bununla birlikte cezeryeye yönelik düşünceler de büyük 
Pazarlama Karmasından Hareketle Coğrafi İşaretli Ürün Algısı: Mersin Örneği

Ozan GÜLER, Metin ÖZTÜRK

oranda 4 ve üzerinde ortalamaya sahiptir. Ancak kerebiç tatlısı söz konusu olduğunda katılımcıların kararsız bir algıya sahip olduğu anlaşılmaktadır. Kerebiçe yönelik en yüksek ve olumlu alg1 'Ürün, Mersin'in imajı için önemli bir üründür”' ifadesinde ortaya çıkmıştır ( $\bar{x}=4.13$ ). Ayırt edici özelliklere sahip olan bu tatlıya yönelik ortaya çıkan bu algı dikkat çekicidir. Buna karşın katılımcılar Kerebiç tatlısının fiyatlandırılması ve tutundurulmasına yönelik algılarının düşük olduğu açık şekilde ortadadır. Katılımcıların kerebiç tatısına yönelik en olumsuz algıları "ürünle bilinirliliği ile ilgili ilgili ülke çapında yeterli tanıtım çalışması yapılmaktadır” ( $\bar{x}=3.03)$ ve "ödediğim paraya değen bir yiyecektir” ( $\bar{x}=3.04)$ ifadelerinde ortaya çıkmıştırtır. Kerebiç tatlısına yönelik algıların genel olarak düşük olması, her bir ifadenin ortalama puanının da belirgin şekilde düşmesine neden olmuştur. İlgili betimleyici istatistikler Tablo 4.'te paylaşılmıştır.

Tablo 4. Ürün Bazlı Coğrafi İşaretli Ürün Algısına Yönelik Betimleyici İstatistikler ( $n=275)$

\begin{tabular}{|c|c|c|c|}
\hline Ölçek İfadeleri & Ürün & Ortalama & $\begin{array}{c}\text { Standart } \\
\text { Sapma }\end{array}$ \\
\hline \multirow[t]{4}{*}{ 1. Tadı güzeldir. } & Tantuni & 4,6145 & 67039 \\
\hline & Cezerye & 4,2145 & ,90081 \\
\hline & Kerebiç & 3,2182 & 1,37351 \\
\hline & Genel & 4,0158 & 1,17972 \\
\hline \multirow[t]{4}{*}{ 2. Yemesi güvenli bir yiyecektir. } & Tantuni & 4,4255 & ,79968 \\
\hline & Cezerye & 4,1709 & ,87330 \\
\hline & Kerebiç & 3,3564 & 1,22188 \\
\hline & Total & 3,9842 & 1,08207 \\
\hline \multirow[t]{4}{*}{ 3. Yeniliğe açık bir yiyecektir. } & Tantuni & 4,3418 & ,90793 \\
\hline & Cezerye & 4,1527 & ,89928 \\
\hline & Kerebiç & 3,2582 & 1,20623 \\
\hline & Total & 3,9176 & 1,11825 \\
\hline \multirow{2}{*}{$\begin{array}{l}\text { 4. Ürün, Mersin’in imajı için önemli bir } \\
\text { üründür. }\end{array}$} & Tantuni & 4,8036 & , 43310 \\
\hline & \begin{tabular}{|l} 
Cezerye \\
\end{tabular} & 4,5055 & ,68012 \\
\hline
\end{tabular}




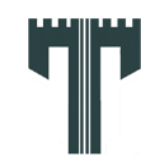

Gastroia: Journal of Gastronomy and Travel Research, Vol. 5, Issue 2,277-301 , 2021

Pazarlama Karmasından Hareketle Coğrafi İşaretli Ürün Algısı: Mersin Örneği Ozan GÜLER, Metin ÖZTÜRK

\begin{tabular}{|c|c|c|c|}
\hline & Kerebiç & 4,1382 & 1,00137 \\
\hline & Total & 4,4824 & ,78980 \\
\hline 5. Sağlıklı bir yiyecektir. & Tantuni & 4,3055 & ,85934 \\
\hline & Cezerye & 4,2691 & ,87146 \\
\hline & Kerebiç & 3,3127 & 1,18554 \\
\hline & Total & 3,9624 & 1,08489 \\
\hline 6. Fiyatı benim için uygundur. & Tantuni & 4,3418 & ,87100 \\
\hline & Cezerye & 4,1382 & ,90568 \\
\hline & Kerebiç & 3,2000 & 1,19610 \\
\hline & Total & 3,8933 & 1,11728 \\
\hline 7. Fiyatı genel olarak tüketiciler için & Tantuni & 4,2873 & ,89668 \\
\hline & Cezerye & 4,0764 & ,94637 \\
\hline & Kerebiç & 3,1709 & 1,19452 \\
\hline & Total & 3,8448 & 1,12891 \\
\hline 8. Her bütçeye uygun farklı fiyat & Tantuni & 4,2873 & ,92473 \\
\hline & Cezerye & 3,9782 & ,97012 \\
\hline & Kerebiç & 3,0618 & 1,16824 \\
\hline & Total & 3,7758 & 1,14988 \\
\hline 9. Ödediğim paraya değen bir & Tantuni & 4,4436 & ,86682 \\
\hline & Cezerye & 4,1855 & 95049 \\
\hline & Kerebiç & 3,0436 & 1,33929 \\
\hline & Total & 3,8909 & 1,23175 \\
\hline 10. Ürün hakkında olumlu yorumlar & Tantuni & 4,5636 & ,60904 \\
\hline & Cezerye & 4,2836 & ,76387 \\
\hline & Kerebiç & 3,4618 & 1,15946 \\
\hline
\end{tabular}




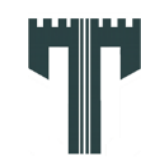

Gastroia: Journal of Gastronomy and Travel Research, Vol. 5, Issue 2,277-301 , 2021

Pazarlama Karmasından Hareketle Coğrafi İşaretli Ürün Algısı: Mersin Örneği

Ozan GÜLER, Metin ÖZTÜRK

\begin{tabular}{|l|l|r|r|}
\hline & Total & $\mathbf{4 , 1 0 3 0}$ & $\mathbf{9 9 1 6 2}$ \\
\hline $\begin{array}{l}\text { 11. Ürünle bilinirliliği ile ilgili ilgili } \\
\text { ülke çapında yeterli tanıtım çalışması } \\
\text { yapılmaktadır. }\end{array}$ & Tantuni & 4,2218 & 1,06276 \\
\cline { 2 - 4 } & Cezerye & 3,9091 & 1,08864 \\
\cline { 2 - 4 } & Kerebiç & 3,0327 & 1,25085 \\
\cline { 2 - 4 } & Total & $\mathbf{3 , 7 2 1 2}$ & $\mathbf{1 , 2 4 2 3 9}$ \\
\hline $\begin{array}{l}\text { 12. Ürünün herhangi bir markasını } \\
\text { hatırlıyorum. }\end{array}$ & Tantuni & 4,5018 &, 78011 \\
\cline { 2 - 4 } & Cezerye & 4,1709 &, 97593 \\
\cline { 2 - 4 } & Kerebiç & 3,3782 & 1,37053 \\
\cline { 2 - 4 } & Total & $\mathbf{4 , 0 1 7 0}$ & $\mathbf{1 , 1 6 8 8 5}$ \\
\hline
\end{tabular}

Üçüncü aşamada, araştırmaya katılan 275 kişinin coğrafi işaretli ürünlere yönelik davranışsal tüketim eğilimlerine cevap aranmıştır. Tablo 5.'teki istatistiklerden görülebileceği üzere katılımcıların 3 coğrafi işaretli ürüne yönelik davranışsal tüketim eğilimlerinin genel ortalama puandan hareketle olumluya yakındır ( $\bar{x}=3.94)$. Tantuni; olumlu konuşma, tavsiye niyeti ve tekrar satın alma niyeti açısından en beğenilen ürün iken cezerye de benzer şekilde olumlu satın alma eğilimine sahiptir. Buna karşın tıpkı Tablo 4.'teki bulguları doğrular şekilde katılımcıların kerebiç tatlısına yönelik davranışsal tüketim niyetleri bu iki ürüne göre açıkca düşüktür.

Tablo 5. Coğrafi İşaretli Ürünlere Yönelik Davranışsal Tüketim Niyeti Betimletici İstatistikleri $(\mathrm{n}=275)$

\begin{tabular}{|l|l|r|r|}
\hline İfadeler & \multicolumn{1}{|c|}{ Ürün } & \multicolumn{1}{|c|}{ Ortalama } & Standart Sapma \\
\hline \multirow{2}{*}{$\begin{array}{l}\text { 1. Bu ürünle ilgili etrafıma olumlu şeyler } \\
\text { söylüyorum. }\end{array}$} & Tantuni & 4,4691 &, 81610 \\
\cline { 2 - 4 } & Cezerye & 4,1709 &, 92997 \\
\cline { 2 - 4 } & Kerebiç & 3,1673 & 1,34042 \\
\cline { 2 - 5 } & Genel Ort. & $\mathbf{3 , 9 3 5 8}$ & $\mathbf{1 , 1 9 0 3 7}$ \\
\hline 2. Bu ürünü çevremdekilere tavsiye ederim. & Tantuni & 4,5345 &, 74094 \\
\cline { 2 - 5 } & Cezerye & 4,2509 &, 89542 \\
\cline { 2 - 5 } & Kerebiç & 3,0909 & 1,34914 \\
\cline { 2 - 4 } & Genel Ort. & $\mathbf{3 , 9 5 8 8}$ & $\mathbf{1 , 2 0 2 0 4}$ \\
\hline
\end{tabular}


Gastroia: Journal of Gastronomy and Travel Research, Vol. 5, Issue 2,277-301 , 2021

Pazarlama Karmasından Hareketle Coğrafi İşaretli Ürün Algısı: Mersin Örneği

Ozan GÜLER, Metin ÖZTÜRK

\begin{tabular}{|l|l|r|r|}
\hline 3. Bu ürünü tüketmeye devam edeceğim. & Tantuni & 4,5527 &, 77832 \\
\cline { 2 - 4 } & Cezerye & 4,2291 &, 90933 \\
\cline { 2 - 4 } & Kerebiç & 3,0255 & 1,38398 \\
\cline { 2 - 4 } & Genel Ort. & $\mathbf{3 , 9 3 5 8}$ & $\mathbf{1 , 2 4 3 2 3}$ \\
\hline
\end{tabular}

\subsection{Fark Testi Bulguları}

Katılımcıların coğrafi işaretli ürünlere yönelik algılarının istatistiksel olarak anlamlı bir şekilde farklılaşıp farklılaşmadığını araştırmak için bir dizi fark testi analiz edilmiştir. Üç farklı ürün; pazarlama karması elemanları ve davranışsal tüketim niyeti açısından Tek Yönlü Varyans Analizi'ne (ANOVA) tabi tutularak, katılımcıların algılarının ürünlerin türüne göre anlamlı olarak değişip değişmediği araştırılmıştır. Gerçekleştirilen ilk ANOVA testi, katılımcıların coğrafi işaretli ürünlerden algıladığ1 "ürün” özelliğinin istatistiksel olarak anlamlı şekilde farklılaşıp farklılaşmadığına yöneliktir. Katılımcıların ürün algısı Tablo 4.’te yer alan ilk beş maddenin ortalamasından hareketle hesaplanmıştır $(\bar{x}=4,07 \pm, 912)$. ANOVA testi bulguları üç ürün açısından anlamlı farklar ortaya çıktığını göstermektedir ( $\mathrm{F}=129,238$; $\mathrm{p}<0,05)$. Bunun üzerine gerçekleştirilen Tukey HSD Post-Hoc testi sonuçlarına göre algılanan ürün özelliğinin üç ürüne göre anlamlı şekilde farklılaştığı görülmektedir $(p<0,05)$. Ortalama puanlar açısından bakıldığında, bu üç ürün arasında en olumlu farkın Tantuni ve Cezerye lehine olduğu söylenebilir. İlgili istatistikler Tablo 6.' da paylaşılmıştır.

Tablo 6. Ürün Değişkenine Göre Post-Hoc Testi Bulguları (n=275)

\begin{tabular}{|l|l|c|c|c|}
\hline \multirow{2}{*}{ Ürün (I) } & Ürün (J) & Ortalamalar Farkı (I-J) & Standart Sapma & p- değeri \\
\hline Tantuni & Cezerye &, $23564^{*}$ & 0,06794 & 0,002 \\
\cline { 2 - 5 }$(\bar{x}=4,49 \pm, 625)$ & Kerebiç & $1,04145^{*}$ & 0,06794 & 0,000 \\
\hline $\begin{array}{l}\text { Cezerye } \\
(\bar{x}=4,26 \pm, 720)\end{array}$ & Tantuni &,$- 23564^{*}$ & 0,06794 & 0,002 \\
\cline { 2 - 5 } & Kerebiç &, $80582^{*}$ & 0,06794 & 0,000 \\
\hline $\begin{array}{l}\text { Kerebiç } \\
(\bar{x}=3,45 \pm, 996)\end{array}$ & Tantuni & $-1,04145^{*}$ & 0,06794 & 0,000 \\
\cline { 2 - 5 } & Cezerye &,$- 80582^{*}$ & 0,06794 & 0,000 \\
\hline
\end{tabular}

*Ortalamalar arasındaki farklar 0,05 düzeyinde anlamlıdır.

Gerçekleştirilen ikinci ANOVA testi katılımcıların coğrafi işaretli ürünlerden algıladığı fiyat özelliğinin istatistiksel olarak anlamlı şekilde farklılaşıp farklılaşmadığına yöneliktir. 
Pazarlama Karmasından Hareketle Coğrafi İşaretli Ürün Algısı: Mersin Örneği

Ozan GÜLER, Metin ÖZTÜRK

Katılımcıların fiyat algısı Tablo 4.'te yer alan 6 ile 9. maddeler arasındaki dört maddenin ortalamasından hareketle hesaplanmıştır $(\bar{x}=3,85 \pm 1,079)$. ANOVA testi bulguları 3 ürün açısından anlamlı farklar ortaya çıktığını göstermektedir $(F=129,118 ; \mathrm{p}<0,05)$. Bunun üzerine gerçekleştirilen Tukey HSD Post-Hoc testi sonuçlarına göre algılanan fiyatın üç farklı ürüne göre anlamlı şekilde farklılaştığ görülmektedir $(\mathrm{p}<0,05)$. Ortalama puanlar açısından bakıldığında, bu üç ürün arasında en olumlu farkın Tantuni ve Cezerye lehine olduğu söylenebilir. İlgili istatistikler Tablo 7.'de paylaşılmıştır.

Tablo 7. Fiyat Değişkenine Göre Post-Hoc Testi Bulguları

\begin{tabular}{|c|c|c|c|c|}
\hline Ürün (I) & Ürün (J) & Ortalamalar Farkı (I-J) & $\begin{array}{c}\text { Standart } \\
\text { Sapma }\end{array}$ & p-değeri \\
\hline Tantuni & Cezerye & ,24545 & 0,08038 & 0,007 \\
\hline$(\bar{x}=4,34 \pm, 807)$ & Kerebiç & $1,22091^{*}$ & 0,08038 & 0,000 \\
\hline Cezerye & Tantuni &,$- 24545^{*}$ & 0,08038 & 0,007 \\
\hline$(\bar{x}=4,09 \pm, 870)$ & Kerebiç & ,97545* & 0,08038 & 0,000 \\
\hline Kerebiç & Tantuni & $-1,22091^{*}$ & 0,08038 & 0,000 \\
\hline$(\bar{x}=3,11 \pm 1,119)$ & Cezerye &,$- 97545^{*}$ & 0,08038 & 0,000 \\
\hline
\end{tabular}

*Ortalamalar arasındaki farklar 0,05 düzeyinde anlamlıdır.

Gerçekleştirilen üçüncü ANOVA testi, katılımcıların coğrafi işaretli ürünlere yönelik "tutundurma algılarının" istatistiksel olarak anlamlı şekilde farklılaşıp farklılaşmadığına yöneliktir. Katılımcıların tutundurma algisı Tablo 4.'te yer alan 10 ile 12 maddeler arasındaki üç maddenin ortalamasından hareketle hesaplanmıştır $(\bar{x}=3,94 \pm, 996)$. ANOVA testi bulguları 3 ürün açısından anlamlı farklar ortaya çıtı̆̆ını göstermektedir ( $F=124,884$; $\mathrm{p}<0,05)$. Bunun üzerine gerçekleştirilen Tukey HSD Post-Hoc testi sonuçlarına göre tutundurma algısının üç farklı ürüne göre anlamlı şekilde farklılaştığı anlaşılmıştır $(p<0,05)$. Ortalama puanlar açısından bakıldığında, bu üç ürün arasında en olumlu farkın Tantuni ve Cezerye lehine olduğu söylenebilir. İlgili istatistikler Tablo 8.'de paylaşılmıştır. 
Gastroia: Journal of Gastronomy and Travel Research, Vol. 5, Issue 2,277-301 , 2021

Pazarlama Karmasından Hareketle Coğrafi İşaretli Ürün Algısı: Mersin Örneği Ozan GÜLER, Metin ÖZTÜRK

Tablo 8. Tutundurma Değişkenine Göre Post-Hoc Testi Bulguları

\begin{tabular}{|l|l|c|c|c|}
\hline \multicolumn{1}{|c|}{ Ürün (I) } & \multicolumn{1}{|c|}{ Ürün (J) } & Ortalamalar Farkı (I-J) & Standart Sapma & p- değeri \\
\hline \multirow{2}{*}{$\begin{array}{l}\text { Tantuni } \\
(\bar{x}=4,42 \pm, 671)\end{array}$} & Cezerye &, $30788^{*}$ & 0,07450 & 0,000 \\
\cline { 2 - 5 } & Kerebiç & $1,13818^{*}$ & 0,07450 & 0,000 \\
\hline $\begin{array}{l}\text { Cezerye } \\
(\bar{x}=4,12 \pm, 806)\end{array}$ & Tantuni &,$- 30788^{*}$ & 0,07450 & 0,000 \\
\cline { 2 - 5 } & Kerebiç &, $83030^{*}$ & 0,07450 & 0,000 \\
\hline $\begin{array}{l}\text { Kerebiç } \\
(\bar{x}=3,29 \pm 1,090)\end{array}$ & Tantuni & $-1,13818^{*}$ & 0,07450 & 0,000 \\
\cline { 2 - 5 } & Cezerye &,$- 83030^{*}$ & 0,07450 & 0,000 \\
\hline
\end{tabular}

*Ortalamalar arasındaki farklar 0,05 düzeyinde anlamlıdır.

Gerçekleştirilen son ANOVA testi, katılımcıların coğrafi işaretli ürünlere yönelik davranışsal niyet algılarının istatistiksel olarak anlamlı şekilde farklılaşıp farklılaşmadığını ortaya koymaya yöneliktir. Katılımcıların davranışsal niyetleri Tablo 5.'te yer alan üç maddenin ortalamasından hareketle hesaplanmıştır $(\bar{x}=3,94 \pm 1,184)$. ANOVA testi bulguları 3 ürün açısından anlamlı farklar ortaya çıktığını göstermektedir $(F=150,609 ; p<0,05)$. Bunun üzerine gerçekleştirilen Tukey HSD Post-Hoc testi sonuçlarına göre davranışsal niyetin üç farklı ürüne göre anlamlı şekilde farklılaştığı görülmektedir $(\mathrm{p}<0,05)$. Ortalama puanlar açısından bakıldığında, bu üç ürün arasında en olumlu farkın Tantuni ve Cezerye lehine olduğu söylenebilir. İlgili istatistikler Tablo 9.'da paylaşılmıştır. 


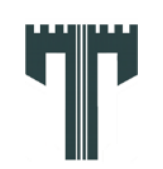

Gastroia: Journal of Gastronomy and Travel Research, Vol. 5, Issue 2,277-301 , 2021

Pazarlama Karmasından Hareketle Coğrafi İşaretli Ürün Algısı: Mersin Örneği

Ozan GÜLER, Metin ÖZTÜRK

Tablo 9. Davranışsal Niyet Değişkenine Göre Post-Hoc Testi Bulguları

\begin{tabular}{|l|l|c|c|c|}
\hline \multirow{2}{*}{ Ürün (I) } & \multicolumn{1}{|c|}{ Ürün (J) } & Ortalamar Farkı (I-J) & Standart Sapma & p- değeri \\
\hline \multirow{2}{*}{$\begin{array}{l}\text { Tantuni } \\
(\bar{x}=4,51 \pm, 753)\end{array}$} & Cezerye &, $30182^{*}$ & 0,08648 & 0,001 \\
\cline { 2 - 5 } & Kerebiç & $1,42424^{*}$ & 0,08648 & 0,000 \\
\hline $\begin{array}{l}\text { Cezerye } \\
(\bar{x}=4,21 \pm, 885)\end{array}$ & Tantuni &,$- 30182^{*}$ & 0,08648 & 0,001 \\
\cline { 2 - 5 } & Kerebiç & $1,12242^{*}$ & 0,08648 & 0,000 \\
\hline Kerebiç & Tantuni & $-1,42424^{*}$ & 0,08648 & 0,000 \\
\cline { 2 - 5 } & Cezerye & $-1,12242^{*}$ & 0,08648 & 0,000 \\
\hline
\end{tabular}

*Ortalamalar arasındaki farklar 0,05 düzeyinde anlamlıdır.

\section{SONUÇ VE ÖNERILER}

Yerli halkın coğrafi işaretli ürünlere yönelik algısını pazarlama karması elemanlarının etkinliği üzerinden araştıran bu çalışma hem alanyazın hem de uygulamacılar açısından tartışılmaya değer sonuçlar ortaya koymuştur. Mersin ile özdeşleşmiş, gerek yerli halkın gerek turistlerin gastronomik deneyimleri açısından en fazla göz önünde olan ve insanların şehirlerarası ziyaretlerinde sıklıkla hediye olarak götürebildiği tantuni, cezerye ve kerebiç tatlısı olmak üzere üç ürün üzerinden bu araştırma gerçekleştirilmiştir. Alanyazında coğrafi işaretli ürünlere yönelik algıları tıpkı bu araştırmada olduğu gibi bir ya da birden fazla ürün özelinde araştıran çalışmalar elbette mevcuttur. Ancak bu araştırmaların büyük bir kısmı coğrafi işaretli ürün algısını boyutları bağlamında fazladan ödeme yapma niyetine etkisi bağlamında incelemiş ve çıkarımlarda bulunmuştur. Bu çalışmada ise şehrin gastronomik bilinirliği, tanınırlığı ve olumlu imajının geliştirilmesi açısında büyük öneme ve değere sahip coğrafi işaretli ürünler (Duman vd., 2019) pazarlama performanslarından hareketle (Örn., Somsong, McNally ve Hsieh (2019) incelenmiştir. Yerli halkın ödeme yapma niyetinden ziyade ürünlerin yerli halk gözündeki değerini ürünlerin kalite, fiyat ve tanıtım gibi performansları açısından ele alarak, halkın ürünlere yönelik davranışsal niyetleri ile birlikte yorumlamak geleceğe yönelik neler yapılması gerektiğine de ışık tutabilir.

Araştırmada elde edilen bulgular Mersin'deki yerli halk arasından araştırmaya katılan bireylerin genel anlamda coğrafi işaretli ürünlere yönelik düşüncelerinin olumluya yakın olduğunu göstermektedir. Katılımcılar sadece ürünlerin fiyatları ve özgünlüğü (farklılığı) noktasında bir kararsızlığa sahiptir. Genel anlamda olumluya yakın bir coğrafi işaretli ürün algısına sahip bu örneklem, ürünler bağlamında değerlendirme yaptığı zaman ortaya daha 
karmaşık bir sonuç çıkmaktadır. Katılımcılar üç ürünün de şehrin imajı için değerli bir ürün olduğu noktasında hemfikir görünmekteler. Ürün özelliği anlamında kendilerine yöneltilen beş ifade içinden "Mersin için önemli bir üründür" ifadesine katılım düzeyi ortaklaşa olarak üç ürün için de yüksektir. Katılımcıların hemfikir oldukları bir diğer konu ise tantuni ve cezerye ürünlerine yönelik algılarının oldukça olumlu bununla birlikte Kerebiç tatlısının ise bu iki ürüne kıyasla belirgin olarak olumsuz olduğudur. Gerek pazarlama karması elemanlarından; ürün, fiyat ve tutundurma, gerekse davranışsal tüketim niyeti değişkenleri açısından bakıldığında Tantuni ve Cezerye birbirine yakın düzeyde olumlu algıya sahip iken, kerebiç tatlısı için benzer şeyleri söylemek mümkün değildir. Bu araştırmada kerebiç tatlısı için ortaya çıkan sonuçlar, Toklu ve Pekerşen'in (2019), Karaman Divle Obruğu tulum peynirinin tutundurma performansı sonuçlarına benzemektedir. Bu bulgular alanyazın açından önemli bir noktaya daha işaret etmektedir. Bir bölgeye ya da şehre ait coğrafi işaretli ürünler üzerinden gerçekleştirilen bütüncül yaklaşımlar yerine tekil ürünler üzerinden gerçekleştirilecek araştırmalar çok daha doğru ve yönlendirici sonuçlar üretebilir. Tıpkı bu araştırmada görüldüğü gibi bazı ürünler çok daha olumlu bir algı ve imaja sahipken, gastronomik değer açısından oldukça önemli olan bir başka ürün farklı algılanabilmektedir. Bu durum Çakaloğlu ve Çağatay’ın (2017) araştırmasında da benzer şekilde ortaya koyulmuştur. Araştırmacıların Finike portakalı üzerine elde ettiği bulgular gayet olumlu iken Antalya Tavşan Yüreği zeytinine yönelik bulguları katılımcılar gözünde marka değerinin dahi henüz oluşmadığını göstermiştir. Dolayısıyla çoklu ürünlerden (Örn., Mercan ve Üzülmez, 2014; Çakaloğlu ve Çağatay, 2017; Somsong, McNally ve Hsieh, 2019) hareketle bölge ya da şehirlerin coğrafi işaretli ürün performansını değerlendirmek daha faydalı olabilecektir.

Araştırmanın sonuçları alanyazına ek olarak uygulayıcılar için de bir dizi çıktı üretmektedir. Gastronomik zenginliği ile ön planda olan Mersin'in gastronomi turizmi açısından daha popüler bir destinasyon olmasında coğrafi işaretli ürünlerinin önemi oldukça büyüktür. Bugün Türkiye'nin hemen her yerinde tantuni, muz, limon, çilek, şalgam, humus dendiği zaman Mersin akla gelmektedir. Bu ürünlerin sahip olduğu ün ve gastronomik değer insanların Mersin'i ziyaret etmelerinde önemli bir motivasyon kaynağı olmaktadır. Bu ürünlerin bir kısmını Mersin'de tüketenler için ise Mersin dışında tüketmek gastronomik deneyim açısından beklentiyi karşılayamamaktadır. Bu nedenlerden dolayı şehrin turizm tanıtımından sorumlu olanlar ve bu ürünlerin üretim ve sunumundan sorumlu olanlar yerli halkın coğrafi işaretli ürünlere yönelik düşünce ve tutumlarını hesaba katmalıdır. Araştırma bulgularından görüleceği üzere kerebiç tatlısına yönelik görüşler diğer ürünlere kıyasla daha olumsuzdur. Katılımcıların görüşleri pazarlama karması elemanlarının boyutları açısından incelendiğinde ürün özelliği açısından ortalama puanlarda iken, fiyat ve tutundurma açısından daha olumsuz bir durum olduğu görülmektedir. $\mathrm{Bu}$ durum doğal olarak tüketicilerin tavsiye niyetlerine de yansımaktadır. 
Araştırmaya katılan 275 kişiden 79'unun kerebiç tatlısını hiç denemediği dahi düşünüldüğünde, kerebiçin daha olumlu bir imaja sahip olması noktasında yapılması gerekenler olduğu söylenebilir. Bu noktada çeşitli öneriler getirilebilir. Kerebiç tatlısının içeriğinde fistık ve ceviz kullanılması ürünün fiyat olarak yüksek olmasına neden olmaktadır. Porsiyon olarak da oldukça büyük olan bu tatlıların gramajlarının küçültülmesi işletmelere fiyat politikası bağlamında yardımcı olacak bir öneri olabilir. Baklava, künefe ve kadayıf gibi şerbetli tatlılar sınıfına giren, çok güçlü rakipleri olan kerebiç için fiyat stratejisi oldukça önemli görünmektedir. Üzerine çöven otundan yapılan köpügün koyularak servis edilen kerebiç için en fazla dile getirilen şikâyetlerden birisi de aşırı doyurucu ve tatlı olması, bu nedenle de bir tane yedikten sonra kişilerde kesilme hissi yaratmasıdır. Zaten un ve irmiğin birlikte kullanımıyla hazırlanan yoğun dış harca, şekerli çöven köpüğü de eklendiğinde yenmesi daha zor bir tatlı haline gelmektedir. Bu noktada şeker kullanımını azaltmak ve glikoz şurubu kullanımından tamamen uzak durmak da bir öneri olabilir. Son olarak araştırmaya katılanların tutundurma performansını da zayıf bulduğu bu kerebiç için hem işletmelerin hem de turizm ve tanıtmadan sorumlu kamu ve sivil toplum kuruluşu yöneticilerinin atması gereken adımlar olmalıdır. Tantuni ve cezeryenin her festival, fuar vb. etkinlikte kolaylıkla tanıtılıyor olmasına karşın kerebiç için bunu söylemek pek mümkün değil. Çöven otundan yapılan köpük, uygun koşullar sağlandığında 24 saate kadar sönmeden tazeliğini koruyabiliyor. Sonuç olarak, Mersin'in bir gastronomi şehri olduğu gerçeğinden hareketle, yerel lezzetlerini önce kendi halkına tanınır ve sevdirir hale getirebilecek faaliyetlere yoğunlaşması, doğal olarak ülke genelinde bilinirliğinin artmasını tetikleyecektir.

$\mathrm{Bu}$ araştırma bir dizi sınırlılığa sahiptir ve sonuçların genellenmesinde bu durumun göz önünde bulundurulması gerekmektedir. Tüm dünyayı etkisi altında bırakan Covid-19 pandemisi nedeniyle araştırmanın örneklem hacmi bir miktar düşük kalmış ve örnekleme yöntemi olarak kolayda örneklem tercih edilmek zorunda kalmıştır. Gelecekteki araştırmaların daha geniş temsiliyeti sağlaması araştırma sonuçlarının karşılaştırılması açısından faydalı olacaktır. Araştırma 3 adet coğrafi işaretli ürün ile sınırlandırılmıştır. Gelecekteki araştırmacılar, Mersin'in diğer coğrafi işaretli ürünlerini de hesaba katarak yerli halkın görüşlerini araştırabilir. Araştırmanın değişkenleri açısından kapsama pazarlama karması elemanlarından dağıtım dâhil edilmemiştir. Gelecek araştırmalar, Mersin dışında yaşayan tüketicilerin Mersin'in coğrafi işaretli ürünlerine yönelik bir araştırma gerçekleştirerek bu değişkeni de modellerine dâhil edebilirler. Son olarak bu araştırmada, ilişkisel bir model altında hipotez testi gerçekleştirilmemiştir. Gelecekti araştırmalarda regresyon analizi ya da yapısal eşitlik modellemesi yardımıyla coğrafi ürünlerin pazarlama performanslarının memnuniyet, daha fazla ödeme isteği ve sadakat gibi çeşitli değişkenlere etkisi araştırılabilir. 


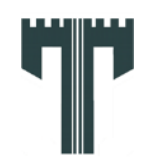

Gastroia: Journal of Gastronomy and Travel Research, Vol. 5, Issue 2,277-301 , 2021

Pazarlama Karmasından Hareketle Coğrafi İşaretli Ürün Algısı: Mersin Örneği

Ozan GÜLER, Metin ÖZTÜRK

\section{KAYNAKÇA}

Adelaja, A. A., Brumfield, R. G. ve Lininger, K. (1990). Product differentiation and state promotion of farm produce: an analysis of the Jersey Fresh Tomato. Journal of Food Distribution Research, (9), 73-86.

Akbaba, A. ve Kendirci, P. (2016) Gastronomi Turizmi ve Coğrafi İşaretlemeli Ürünler. (Ed.) Özdoğan O., N., Yiyecek içecek endüstrisinde trendler kavramlar yaklaşımlar başarı hikayeleri II içinde (113-128). Ankara: Detay Yayıncılık.

Andersson, T., D., Mossberg, L. ve Therkelsen, A. (2017). Food and tourism synergies: perspectives on consuption, production and destination devolopment. Scandinavian Journal of Hospitality and Tourism 17(1), 1-8.

Aprile, M. C., Caputo, V. ve Nayga R., M. Jr. (2012). Consumers' valuation of food quality labels: the case of the european geographic indication and organic farming labels. International Journal of Consumer Studies, (36), 158-165.

Aytop, Y. ve Şahin, A. (2014) Coğrafi işaretli Gemlik Zeytinine ilişkin tüketici t ercihleri: Kahramanmaraş kent merkezi örneği. XI. Ulusal Tarım Ekonomisi Kongresi Bildirisi, 13011308. Ondokuz Mayıs Üniversitesi Ziraat Fakültesi Tarım Ekonomisi Bölümü: Samsun.

Bekar, A. ve Karakulak, Ç. (2017) Coğrafi İşaretleme Yoluyla Gastronomik Kimlik Oluşturma ve Gastronomik Kimliğin Destinasyon Pazarlamasındaki Rolü: Trakya Örneği. (Ed): Bozok, D., Avcıkurt, C., Doğdubay, M., Sarığlan, M. ve Girgin, G.,K. Gastronomi üzerine araştırmalar içinde (156-174). Ankara: Detay Yayıncılık.

Bucak, T. (2018) Coğrafi İşaretleme. (Ed): Akbaba, A., Çetinkaya, N., Gastronomi ve yiyecek tarihi İçinde (373-391). Ankara: Detay Yayınc1lı.

Büyüköztürk, Ş., Çakmak, E.K., Akgün, Ö.E., Karadeniz, Ş. ve Demirel, F. (2012). Bilimsel Araştırma Yöntemleri. Ankara: Pegem Akademi.

Chambers, S., Lobb, A., Butler, L., Harvey, K., ve Traill, W. B. (2007). Local, national and imported foods: A qualitative study. Appetite, 49(1), 208-2013.

Costanigro, M., Kroll, S., Thilmany, D. ve Bunning, M. (2014). Is it love for local/ organic or hate for conventional? asymmetric effects of information and taste on label preferences in an experimental auction. Food Quality and Preference, (31), 94-105.

Cömert, M. (2014) Turizm pazarlamasında yöresel mutfakların önemi ve Hatay Mutfağı örneği. Journal of Tourism and Gastronomy Studies, (2)1, 64-70.

Çalışkan, V. ve Koç, H. (2012). Türkiye'de coğrafi işaretlerin dağılış özelliklerinin ve coğrafi işaret potansiyelinin değerlendirilmesi. Doğu Coğrafya Dergisi, 17(28), 193-214. 
Gastroia: Journal of Gastronomy and Travel Research, Vol. 5, Issue 2,277-301 , 2021

Pazarlama Karmasından Hareketle Coğrafi İşaretli Ürün Algısı: Mersin Örneği

Ozan GÜLER, Metin ÖZTÜRK

Çakaloğlu, M. ve Çağatay, S. (2017). Coğrafi işaretler ve marka değerine sahip ürünlere yönelik tüketici algısı: Finike Portakalı ve Antalya Tavşan Yüreği Zeytini örnekleri. Türkiyat Araştırmaları Enstitüsü Dergisi, 3(1), 52-65.

Çam, A., V., Ayaydın, H., Pala, F. ve Barut, A. (2018). Turistlerin coğrafi işaretli ürün algısının turizm gelirleri açısından değerlendirilmesi. Sosyal Bilimler Enstitüsü Dergisi, 3(18), Özel Say1, 69-84.

Çapar, G. ve Yenipınar, U. (2016). Somut Olmayan Kültürel Miras kaynağı olarak yöresel yiyeceklerin turizm endüstrisinde kullanılmas1. Journal of Tourism and Gastronomy Studies, 4/Special Issue 1, 100-115.

Doğan, B. (2015). Coğrafi işaret korumasının gelişmekte olan ülkeler için önemi. Social Sciences, $10(2), 58-75$.

Duman, S., Tanrısever, C. ve Pamukcu, H. (2019). Kastamonu Ilgaz Dağı Milli Parkı'na gelen turistlerin coğrafi işaretli ürün algısı. Journal of Tourism and Gastronomy Studies, 7(2), 818838.

Durlu-Özkaya, F., Sünnetçioğlu, S. ve Can, A. (2013). Sürdürülebilir gastronomi turizmi hareketliliğinde coğrafi işaretlemenin rolü. Journal of Tourism and Gastronomy Studies, $1(1), 13-20$.

Durusoy, Y., Y. (2017). Coğrafi işaretli gastronomik ürünlerin bölge halkı tarafindan algılanması üzerine analitik bir araştırma: Kars Kaşarı örneği. Haliç Üniversitesi Sosyal Bilimler Enstitüsü İşletme Anabilim Dalı İşletme Yönetimi Doktora Programı Doktora Tezi.

Feldmann, C., Hamm, U. (2014). Consumers perceptions and preferences for local food: a review. Food Quality and Preference, 40, 152-164.

Giovannucci, D., Barham, E. ve Pirog, R. (2010). Defining and marketing "Local” foods: Geographical indications for US products. The Journal of World Intellectual Property, 13(2), 94-120.

Gökovalı, U. (2007). Coğrafi işaretler ve ekonomik etkileri: Türkiye örneği. İktisadi ve İdari Bilimler Dergisi, 21(2), 141-160.

İbret, Ü. ve Küllü, N. (2007). Kastamonu'nun coğrafi işaretli marka ürünü: Taşköprü Sarımsağı. [URL:http://earsiv.kastamonu.edu.tr:8080/http://earsiv.kastamonu.edu.tr:8080/xmlui/handl e/123456789/409] adresinden erişilmiştir. Erişim Tarihi: 08.08.2020.

Jekanowski, M. D., Daniel, R. W. II., ve Schick, W. A. (2000). Consumers' willingness to purchase locally produced agricultural products: An analysis of an Indiana survey. Agricultural and Resource Economics Review, 29(8), 43-53.

Karasar, N. (2014). Bilimsel araştırma yöntemi. Ankara: Nobel Yayın Dağıtım. 
Gastroia: Journal of Gastronomy and Travel Research, Vol. 5, Issue 2,277-301 , 2021

Pazarlama Karmasından Hareketle Coğrafi İşaretli Ürün Algısı: Mersin Örneği

Ozan GÜLER, Metin ÖZTÜRK

Kargiglioğlu, Ş., Çetin, Y., Erkol Bayram, G. (2019). Gastronomi turlarının coğrafi işaretli ürünler aracılığı ile oluşturulması: Batı Karadeniz turları örneği. Gastroia: Journal of Gastronmy and Travel Research, 3(18), Özel Sayl, 624-639.

Lee, L., E., Niode, O., Simmone, A., H. ve Bruhn, C., M. (2012). Consumer perceptions on food safety in Asian and Mexican restaurant. Food Control, 26, 531-538.

Lertputtarak, S. (2012). The relationship between destination image and revisiting Pattaya, Thailand. International Journal of Business and Management, 7(5), 111-122.

Lim, K. H., ve Hu, W. (2012). How local is local? Consumer preference for steaks with different food mile implications. In Selected Paper for Presentation at the American Agricultural Economics Association Annual Meeting, (2), 2-19.

Mascarello, G., Pinto, A., Parise, N., Crovato, S. ve Ravarotto, L. (2015). The perception of food quality. Profiling Italian consumers. Appetite, (89), 175-182.

McCluskey, J. J. ve Loureiro, M., L. (2003). Consumer preferences and willingness to pay for food labeling: A discussion of empirical sudies. Journal of Food Distribution Research, 34(3), 95-102.

Mercan, Ş., O. ve Üzülmez, M. (2014). Coğrafi işaretlerin bölgesel turizmin gelişimindeki önemi: Çanakkale ili örneği. Dokuz Eylül Üniversitesi İktisadi ve İdari Bilimler Fakültesi Dergisi, 29(2), 67-94.

Oraman, Y. ( 2015). Türkiye'de coğrafi işaretli ürünler. Balkan ve Yakın Doğu Sosyal Bilimler Dergisi, 1(1), 76-85.

Orhan, A. (2010). Yerel değerlerin turizm ürününe dönüştürülmesinde coğrafi işaretlerin kullanımı: İzmit Pişmaniyesi örneği. Anatolia Turizm Araştırmaları Dergisi, 21(2), 243-254.

Patterson, P. M., Olofsson, H., Richards, T. J. ve Sass, S. (1999) An empirical analysis of state agricultural product promotions: A case study on Arizona Grown. Agribusiness, 15(2), 179 196.

Sekaran, U. (1992). Research methods for business: A skill- building approach. John Wiley \& Sons.

Somsong, P., McNally, R., C. ve Hsieh C. (2019) Consumers perceptions towards Thai Rice, A crosscultural comparison between easterners and westerners. British Food Journal, 122(1), 151169.

Sünnetçioğlu, S., Can, A. ve Durlu-Özkaya, F. (2012). Yavaş turizmde coğrafi işaretlemenin önemi 13. Ulusal Turizm Kongresi. Antalya.

Tanrıkulu, M. (2007). Türkiye'de coğrafi işaretlerin tespiti ve tescil edilmesinin önemi. Uluslararası Sosyal Bilimler Eğitimi Dergisi, 1(2), 173-184. 
Gastroia: Journal of Gastronomy and Travel Research, Vol. 5, Issue 2,277-301 , 2021

Pazarlama Karmasından Hareketle Coğrafi İşaretli Ürün Algısı: Mersin Örneği Ozan GÜLER, Metin ÖZTÜRK

Toklu, İ., T., Ustaahmetoğlu, E. ve Öztürk Küçük, H. (2016). Tüketicilerin coğrafi işaretli ürün algıs1 ve daha fazla fiyat ödeme isteği: Yapısal eşitlik modellemesi yaklaşımı. Celal Bayar Üniversitesi İktisadi ve İdari Bilimler Fakültesi Yönetim ve Ekonomi Dergisi, 23(1), 145161.

Toklu, S., Pekerşen, Y. (2019). Coğrafi işaretli gastronomik bir değer olan Karaman Divle Obruğu Tulum Peyniri' nin bölge halkı tarafindan algılanması. Journal of Tourism and Gastronomy Studies, 7(3), 2251-2273.

Türk Patent ve Marka Kurumu (2021a). Coğrafi işaret nedir? [URL: https://ci.turkpatent.gov.tr/sayfa/co\%C4\%9Frafi-i\%C5\%9Faret-nedir] adresinden erişilmiştir. Erişim Tarihi: 08.04.2021.

Türk Patent ve Marka Kurumu (2021b). Tescil ve Başvuru Sayıları [URL: https://ci.turkpatent.gov.tr/Statistics/RegistrationAndApplication] adresinden erişilmiştir. Erişim Tarihi: 09.06.2021.

Türk Patent ve Marka Kurumu (2021c). Tescil Türleri [URL: https://ci.turkpatent.gov.tr/Statistics/Type] adresinden erişilmiştir. Erişim Tarihi: 09.06.2021.

Türk Patent ve Marka Kurumu (2021d). Tescilli Coğrafi İşaretlerin Ürün Gruplarına Göre Dağılımı [URL: https://ci.turkpatent.gov.tr/Statistics/ProductGroup] adresinden erişilmiştir. Erişim Tarihi: 09.06.2021.

Türk Patent ve Marka Kurumu (2021e). Mersin ili coğrafi işaretli ürünleri [URL: https://ci.turkpatent.gov.tr/veri-tabani] adresinden erişilmiştir. Erişim Tarihi: 08.04.2021.

UNESCO Türkiye Milli Komisyonu (2020). Somut olmayan kültürel miras listelerinde Türkiye. [URL:https://www.unesco.org.tr/Pages/126/123/UNESCO\%C4\%B0nsan1\%C4\%B1\%C4\% 9F\%C4\%B1nSomut-Olmayan-K\%C3\%BClt\%C3\%BCrel-Miras\%C4\%B1Temsil\%C3\%AE-Listesi] adresinden erişilmiştir]. Erişim Tarihi: 07.09.2020.

Üzümcü, T. P., Alyakut, Ö. ve Adalet Akpulat, N. (2017). Coğrafi işaretleme kapsamında Kocaeli gastronomik ürünlerin değerlendirilmesi, KMU Sosyal ve Ekonomik Araştırmalar Dergisi, $19(28), 132-140$.

Vatansever, Deviren, N., Yıldız, O. (2017). Coğrafi işaretlerin bölgesel turizm açısından değerlendirilmesi: Muğla örneği. International Journal of Social Science, 62, 511-523.

Yüncü, H.R. (2010). Sürdürülebilir turizm açısından gastronomi turizmi ve Perşembe Yaylası. 11 10. Aybast1-Kabataş Kurultayı, (ss: 27-34). Ankara.

Zepeda, L. ve Leviten-Reid, C. (2004). Consumers' views on local food. Journal of Food Distribution Research, 35(3), 1-6. 